\title{
Relationship Between CSR Quality with Corporate Reputation PT Indonesia Power UP Semarang
}

\author{
Agus Naryoso ${ }^{1}$ \\ ${ }^{1}$ Information and Public Relations Department, Vocational School, Diponegoro University \\ Corresponding Author's Email : agusnaryoso@gmail.com
}

\begin{abstract}
PT Indonesia Power UP Semarang has organized various activities as a social responsibility for the community. The Corporate Social Responsibility (CSR) activities of the company are already established so that it produces a positive impact on the people who receive it. PT Indonesia Power UP Semarang committed to helping Micro, Small and Medium Enterprises (MSMEs) to continue to increase their potential to create works that have a positive impact on the economy and other aspects so that the fostered partners can be independent. CSR as a form of corporate goodwill in developing good relations with the community will be a priority on positive companies. This study uses explanatory research methods that can be accepted between variables with the Pearson test of 30 respondents who receive CSR benefits and live around the company site. Based on hypothesis testing conducted using Pearson analysis, it shows the relationship between CSR quality variables and those recognized by the company. It is evidenced by the high Pearson conversion coefficient with a value of 0.470 and a significance value of 0.009 . This value represents the difference between CSR quality and company awards. It is contrary to the theory of Griffin (2008), which stated that corporate social responsibility is one of the factors forming corporate or management trust.
\end{abstract}

Keywords: CSR, quality, reputation, company, Indonesia Power

\section{INTRODUCTION}

Based on Law No. 40 of 2007 concerning Limited Liability Companies, social and environmental responsibility is the company's commitment to participate in sustainable economic development in order to improve the quality of life and the environment that benefits both the company itself, the local community, and the society. PT Indonesia Power following its mission "Conducting Power Generation and Eco-Friendly Service-Related Business" run a program for environmental management by participating in making a toilet concept project in Wonosobo District for 1,600 families. PT Indonesia Power UP Semarang also launched a CSR budget of up to IDR 
217 million in the fourth quarter of 2017. This CSR is channelled through two excellent target groups, including mangrove and milkfish cultivation.

PT Indonesia Power is a state electricity company (PLN) running a commercial business in the field of electricity generation with the largest power capacity in Indonesia. It is founded on October 3, 1995, under the name of PT PLN Pembasing Jawa Bali (PT PJB I). On October 8, 2000, PT PJB I changed its name to Indonesia Power as an affirmation of the company's goal to become a purely business-oriented independent power generation company. The company's primary business activity at the moment is to focus on providing electricity through the generation of electricity that operates plants which spread throughout Indonesia. In addition to managing the generating unit, Indonesia Power has five subsidiaries, two joint ventures companies, one associate company, three affiliates of the subsidiary to support the company's business strategy and business processes.

PT Indonesia Power UP Semarang is committed to helping MSMEs to continue to explore their potential to create works that have a positive impact on the economy, one of which is by holding a Semarang Micro Finance batik exhibition as an independent economic step for fostered partners. Corporate Social Responsibility (CSR) is a form of goodwill in building relationships with community stakeholders so that it will have an impact on the non-material profit that benefits from the long-term investment process. The fact shows that there are still residents who have not felt the benefits or real impact of CSR activities performed by PT Indonesia Power UP Semarang. Numerous residents who are around PLN Semarang Generating Unit complained of noise pollution caused by the generator engine.

Based on the description above, the problems we can formulate are as follows: Is there a relationship between the quality of PT Indonesia Power UP's CSR and the company's reputation? The quality of CSR is a subjective assessment of the community towards corporate social responsibility activities carried out by a company. Company reputation is an award obtained because of the advantages that exist in the company, namely the company capability to develop itself to continue to create new things for the fulfilment of consumer needs. Besides that, there is also a high degree of integrity from the service provider for the services provided to consumers so that the company can provide the best service.

The quality of CSR provided by PT Indonesia Power UP is associated with the reputation of the company by using the theory of public opinion. The theory of public opinion relates to the reputation of the public and is related to trust. The duty of a PR to influence, shape, change, or maintain public opinion to match what the company wants is expressed by Stephen W. Littlejohn, which means that one of the ways in public relations to form, change or maintain public opinion is to carry out CSR activities. CSR activities are essential to improve the company's reputation, which in turn increases the trust of both consumers and business partners of the company. If the 
company's CSR activities meet the quality standards of CSR required by the public / the intended community, then the public will form an opinion following the quality of the company's CSR. This public opinion will affect the company's reputation. Positive opinion will raise or maintain the company's reputation and vice versa.

The hypothesis of this study is that "there is a relationship between the quality of PT Indonesia Power UP's CSR with the company's reputation”. This study is quantitative research with explanatory type. This study was conducted on people who are the fostered members of PT Indonesia Power UP's CSR activities. The data used is data that has been collected by researchers from interviews with questionnaires as a means of collecting data. The data analysis technique was performed using a crosstabulation test and Pearson correlation test.

\section{DATA ANALYSIS AND DISCUSSION}

The purpose of this study is to find out the relationship between CSR quality and the reputation of PT Indonesia Power UP Semarang. Based on the questionnaire data collected, researchers will process and analyze quantitatively. Quantitative is a process of finding knowledge by using data in the form of numbers as a means of analyzing information about what we want to know (Qualitative and Quantitative Research Methodology, Kasiram, 2008: 149). In this study, there were 30 respondents, 9 men and 21 women who were fostered members of the PT Indonesia Power UP Semarang CSR. The samples we took were Putri Laut MSME, Iwak Nyus SME, Batik Alam MSME, Waste Bank MSME.

Cross tabulation and correlation test were used in this study to determine the relationship of CSR quality with the reputation of PT Indonesia Power UP Semarang. Of all the questions on the Quality Power CSR Indonesia variable that has been calculated, the results showed that as many as 23 respondents or $77 \%$ acknowledged the company to have good CSR quality. It can be seen from the number of respondents who received various positive impacts from CSR activities; almost all respondents felt positive impacts, such as increased employment, increased income, improved health, infrastructure, and preserved culture.

Meanwhile, the variable Company Reputation that has been analyzed showed that almost all respondents stated that the reputation of PT Indonesia Power UP Semarang had an excellent reputation. There are $57 \%$ of respondents who answered the company's reputation very well. In terms of whether PT Indonesia Power UP is the leader in supplying electricity, respondents said that Indonesia Power is a large electricity company with a production target that is always achieved. Also, almost no problems were found in their electricity needs, where electricity supply obtained from PT Indonesia Power UP Semarang was always stable and met with minimal risk of work accidents. It indicates that PT Indonesia Power UP Semarang always uses the latest technology so that it is more advanced and the problem is minimized. 
According to Herbig, Millewicz, and Golden in Rofifah Mau'idzah journal, the company's reputation is an award obtained by the companies because of the advantages that exist within them, namely the ability of the company so it will continue to develop itself to continue to create new things for meeting the needs of consumers. Besides that, there is also a high degree of integrity from the service provider for the services provided to consumers so that the company can provide the best service.

The factors that caused PT Indonesia Power UP's CSR reputation to be good are as follows:

a) Indonesia Power is able to perform good social responsibility and comply with legislation through quality CSR activities.

b) CSR activities performed to have a positive impact on people's lives from economic, environmental, educational, health, and infrastructure factors

c) Direction and staff of PT Indonesia Power UP Semarang have good quality. The direction has a positive attitude and good commitment, responsibility towards the environment, as well as being obedient to the government's appeals and legal obligations. Staff have special attention to ongoing CSR programs, find out the problems that occur, always surveying the shortcomings of existing programs, and help provide evaluations of programs that have been completed by the community.

d) The availability of the company to share business profits by CSR assistance in the form of money and MSMEs support tools that will be used as return capital to the community. This shows ethical business awareness.

e) PT Indonesia Power pays attention to the difficulties of the surrounding community. It is evident from the provision of chimneys in the Bandarharjo fish fumigation area, because of empathy for the difficulties of the surrounding community who are difficult to breathe due to the smoke generated from the fish factory. In addition, Indonesia Power also provided entrepreneurial assistance to the people of Kampung Malon in the form of batik training to open jobs for housewives with economic difficulties.

f) PT Indonesia Power UP is coordinative, easy to work with, and always meets the needs raised by the community with existing provisions, smooth communication, and assistance that adjusts the availability of supporting resources.

g) PT Indonesia Power UP is responsible for the negative impacts caused by their business. The company takes care of its business activities to not causing problems in the surrounding environment.

The tabulation results showed the tendency of the relationship between the quality of PT Indonesia Power UP Semarang and the company's reputation. It can be interpreted that company which have an excellent CSR quality will produce a good 
reputation. Conversely, the lower the quality of CSR provided, the worse the reputation of the company.

Public Opinion Theory is related to trust. According to Stephen W. Littlejohn in Encyclopedia of Communication Theory, Public Opinion is divided into three factors, namely; attitude, opinion, and behaviour. The theory explains that if public attitudes become strong, attitudes will form opinions, and strong opinions will shape action. In Public Opinion Theory, if the company's CSR activities meet the quality standards of CSR required by the public/the intended public, the public will form an opinion following the quality of the company's CSR. (Encyclopedia of Communication Theory, 2009: 808). This public opinion will affect the company's reputation. Positive opinions can raise or maintain a company's reputation and vice versa. The opinion will also influence public attitudes to be positive or negative towards the company.

\section{CONCLUSION}

Based on research that has been done by testing the variable of Relationship between CSR Quality with the Reputation of PT Indonesia Power UP Semarang, it can be concluded that there is a relationship tendency. This was proven by using the bivariate correlation test that found a number that explains the level of closeness of the relationship, which is in a steady category of 0.470 and the significance value of 0.009 . These results state that the better the quality of CSR, the better the reputation held by PT Indonesia Power UP Semarang. However, the lower the quality of CSR, the worse the reputation of PT Indonesia Power UP Semarang.

The study concluded that the quality improvement of CSR would improve good opinions on the company's reputation from respondents' ratings. Suggestions for PT Indonesia Power UP Semarang and related parties are the following:

1) The company should conduct a Social Mapping survey by considering aspects of Boundary Spanning (Outside in Thinking), not solely on the aspect of linkages (public interest).

2) The company should conduct regular monitoring of the members of the MSMEs fostered, as well as preparing a CSR Assistance SOP.

3) The company are more open to fostered members regarding the funds provided to reduce negative prejudice and build a more cooperative nature between the company and the beneficiaries. 


\section{REFERENCES}

\section{Book/Journal}

Constitution of the Republic of Indonesia Number 40 of 2007 and Presidential Decree of the Republic of Indonesia Year 2014 Concerning Limited Liability Company

Kasiram, Moh, 2008, Metodologi Penelitian, Malang : UIN-Malang Pers

Little John, Stephen W. \& Karen A. Foss. 2009. Encyclopedia of Communication Theory. Thousand Oaks California: Sage Publications, Inc

Nursyahid, 2006, Jurnal Ilmu Sosial dan Ilmu Politik Volume 12 No.1 https://media.neliti.com/media/publications/37799-ID-program-csr-berbasispemberdayaan-masyarakat-menuju-kemandirian-ekonomi-pasca-ta.pdf

Ruslan, Rosady, 2010, Manajemen Public Relations dan Media Komunikasi, Jakarta: Rajawali Pers

Rusmana, Agus, 2019, The Future of Organizational Communication In The Industrial Era 4.0: Book Chapter Komunikasi Organisasi, Bandung : Media Akselerasi

Yusuf, Wibisono, 2007, Membedah Konsep dan Aplikasi CSR (Corporate Social Responsibility), Jakarta : PT Gramedia

\section{Internet}

https://www.google.co.id/amp/s/jateng.tribunnews.com/amp/2017/10/29/wargaminta-indonesia -power-kecilkan-kebisingan-mesin-pembangkit-listrik, accessed on March 10, 2019 at 10.12 a.m. Western Indonesia Time https://indonesiapower.co.id/id/komunitas-dan-lingkungan/berita-csr/Default.aspx, accessed on March 11, 2019 at 12.57 a.m. Western Indonesia Time https://jateng.tribunnews.com/amp/2017/11/01/setelah-dicek-kebisingan-yangdikeluhkan- warga-rt-06-tanjung-mas-semarang-di-bawah-batas-normal, accessed on March 11, 2019 at 01.23 p.m. Western Indonesia Time 